Review Article

\title{
Usnic acid biological activity: history, evaluation and usage
}

\begin{abstract}
Ahlam Abdulaziz Alahmadi*
Department of Biological Sciences, Faculty of Science, King Abdulaziz University, Jeddah, Saudi Arabia

Received: 12 October 2017

Revised: 23 October 2017

Accepted: 26 October 2017

\section{*Correspondence to:}

Dr. Ahlam Abdulaziz Alahmadi, Email: aaalahmadi1@kau.edu.sa

Copyright: (C) the author(s), publisher and licensee Medip Academy. This is an openaccess article distributed under the terms of the Creative Commons Attribution Non-

ABSTRACT

Since Usnic acid (UA) was isolated from lichen metabolite in 1844, a lot of studies were conducted on it and now it became commercially available in the market. Its wide availability in different lichen species, being isolated easily, and high purity of the is olated product make it an excellent base for producing new pharmaceuticals. In this review the different usage of UA was summarized. It was utilized as an antioxidant, anti-proliferative, antimicrobial and antiprotozoal, larvicidal and insecticidal, antifungal, antiviral, algicidal, anti-inflammatory, pain-relieving and antipyretic agent. Many adverse effects were associated with using usnic acid, especially at high dose, including; hepatotoxicity, genotoxicity, allergenicity, side effects on the cardiovascular system and adipocytes of fatty tissue. This review aimed to throw the light on the updated biological activities, effectiveness and safety and usage of usnic acid during the last decade.
\end{abstract} Commercial License, which permits unrestricted noncommercial use, distribution, and reproduction in any medium, provided the original work is properly cited.
Keywords: Animal, Cytotoxicity, Human, Hepatotoxicity, Lichen, Nephrotoxicity, Neurotoxicity, Usnic Acid

\section{INTRODUCTION}

Lichens are a group of composite organisms that actually are composite organisms formed by a symbiotic relationship between a fungus (mycobiont) and an algal or cyanobacteria. In the symbiotic cooperation, the bacteria provide the fungus with its organic metabolites and the fungus supply water with dissolved mineral salts..$^{1-3}$ Lichens able to live and survive under excessive life conditions, where they can live in air, rainfall, dew, fog, and soil. It is estimated that lichens cover around $8 \%$ of the earth surface with more than 17,000 species and over 800 lichen products are known. ${ }^{4} \mathrm{~A}$ lot of researchers were interested in lichens products, such as polysaccharides, proteins and secondary metabolites regarding their biological activities as medications, food supplements, dyes, where the most famous lichen secondary metabolite is usnic acid (UA). ${ }^{2}$ First time to isolate Usnic acid (UA) from lichen metabolite was in 1844, and from that year a lot of studies were done on UA, and it became commercially available. Its wide availability in different lichen species, the easy procedure of isolation, and high purity of the isolated product make it an excellent base for producing new pharmaceuticals, where it shows biological and physiological characteristics such as antiinflammatory, analgesic, healing, antioxidant, antimicrobial, antiprotozoal, antiviral, larvicidal and UV protection. On the other hand, several studies reported liver toxicity and contact allergy. ${ }^{1-3}$ This review of the 
biological activity of UA aimed to review the publications of UA (effectiveness and safety) during the last decades.

In the Traditional Chinese Medicine, the first used and record of U. species was found in dates to 101 B.C as antimicrobial with the name "Song Lo. Song Lo tea", it was used for cleaning the liver, treating malaria, healing wounds and snake bite with common dose 6-9g of dried lichen, it was classified as rare medication. ${ }^{4}$

For long time it was used as antibacterial in many nations and being utilized as a modern pharmaceutical till the penicillin antibiotics were discovered. ${ }^{3}$ Where it was used as main agent or as preservative for treating pulmonary tuberculosis, pain, fever, wounds, athlete's foot, deodorants, and herbal tinctures, with different names regarding the country, in Germany "Monogram", in Finland, "Rosalina Thrust" and in Argentina, "Barba del la Piedra". ${ }^{4}$ From the end of $2^{\text {nd }}$ world war to 1950 s, the work on UA focused on its antimicrobial activity. Then it was activated again in 1980s due to the problem bacterial resistance. ${ }^{3}$

\section{Nature of usnic acid}

Usnic acid is produced from several lichen genera such as Cladonia (Cladoniaceae), Usnea (Usneaceae), Lecanora (Lecanoraceae), Ramalina (Ramalinaceae), Evernia, Parmelia (Parmeliaceae), Alectoria (Alectoriaceae). ${ }^{1}$ See Figure 1. Ramalina was the first genra to is olate usnic acid in 1843, after one year it was distinguished from other substances and get its name, later by nine decades the chemical structure was determined. ${ }^{4}$

Castle and Kubsch were the first to report that UA is produced within the mycobiont (fungal part) of the lichen and then make a layer on the surface of the photobiont. ${ }^{5}$ Lichens' usnic acid content relies on several factors: geographic location, the time of summer solstice, insolation, and temperature. Where UA represents up to $8 \%$ of dry weight regarding seasons with the highest level in late spring and early summer and lower levels in autumn and winter. ${ }^{6-7}$

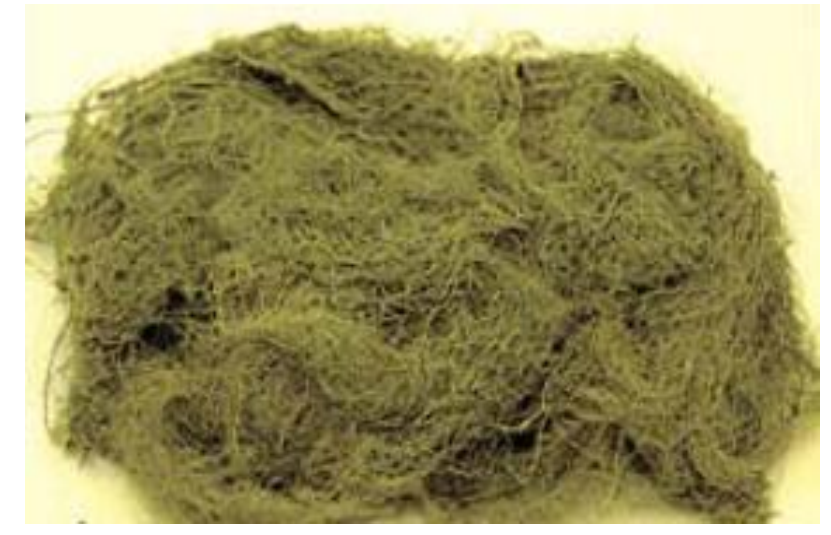

Figure 1: Usnea articulata which collected from AlSawda mountain, the Asir region in Saudi Arabia.

\section{Structure of usnic acid}

Usnic acid was isolated for the first time as yellow and crystalline a secondary lichen metabolite by the German scientist Knop in $1844{ }^{8}$ The full scientific name is [2, 6diacetyl- 7, 9-dihydroxy-8, 9 b-dimethyl-dibenzofuran-1, $3(2 \mathrm{H}, 9 \mathrm{bH})-$ Dione $]$, it has two enantiomers; (+) D-usnic acid and (-) L-usnic acid, due to $\mathrm{R}$ or $\mathrm{S}$ dropping of the angular-CH3 group at position 9b (Figure 2). Each enantiomer has different biological activities. Two other natural isomers $(+)$ and $(-)$ isousnic acids [2, 8-diacetyl-7, 9-dihydroxy-6, 9b-dimethyldibenzofuran-1, 3(2H, 9bH)Dione were found in lichens. 4 On the other hand, UA can be chemically synthesized from methylphloroacetophenone first by oxidative coupling, then by hydrolysis in sulfuric acid. ${ }^{9}$

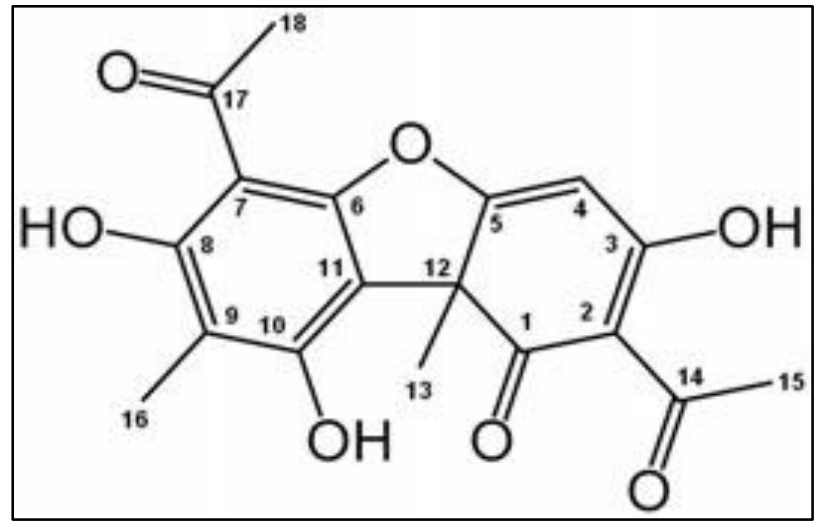

Figure 2: UA structure (adapted from Ingolfsdottir). ${ }^{9}$

\section{Pharmacokinetics of usnic acid}

There is limited number of studies described the in vivo pharmacokinetics of UA including absorption, distribution, metabolism and excretion. ${ }^{10} \mathrm{~A}$ study on rats received parenteral UA (25mg $\mathrm{kg} 1$ ) showed that UA was distributed into different tissues with high levels in liver and lung tissue followed by blood with "mean tissue/plasma ratios of 1.78". Another study on rabbits received UA (25mgkg 1) by oral administration showed a plasma concentration of $32.56 .8 \mathrm{mgml} 1$ in $12.23 .8 \mathrm{~h}$. This indicated that UA was widely bound to protein with approximately $99.2 \%$ of bound. ${ }^{11}$ In 2008 a study was conducting to evaluate the metabolism of UA in isolated" human liver microsomes pre-incubated with UA and several CYP inhibitors". ${ }^{12}$ The authors reported that the oxidative metabolism of UA is mainly mediated by CYP1A2. In this study, it was mentioned that the half-life of UA in human liver microsomes was $19.3 \mathrm{~min}$ with an intrinsic clearance of $45.24 \mathrm{ml} / \mathrm{min} \mathrm{kg} 1$. Similar result was found in another study on $2011 .{ }^{13}$

Studying the effect of UA on the functions of mitochondria was the focus of many studies. One of the early studies was by Johnson and colleagues on 1950 on the homogenates of liver and rat, they found two actions regarding UA concentration, at $1 \mu \mathrm{M}$, encouraged oxygen consumption in 
the existence of several substances. ${ }^{14}$ At higher concentrations $(8-30 \mu \mathrm{M})$, phosphate uptake was decreased regardless a parallel fall in oxygen consumption. They induced these actions to uncoupling of oxidative phosphorylation. Similar result was found by Pramyothin and co-workers study, where the results showed that UA encouraged "oxygen consumption" by inducing highest stimulation of respiration (in the absence of ADP, state4). ${ }^{15}$ Han et al, confirmed a similar uncoupling effect of UA in the presence of bovine serum albumin in buffer. ${ }^{16}$ While in the absence of BSA in buffer in primary mouse hepatocytes and rat liver mitochondria, UA acted as an uncouple as well as an inhibitor of mitochondria. ${ }^{4}$ During 2010 in Brazil and 2013 in Russia two studies were conducting to detect the mechanis m on UA on tuberculosis and influenza A, where the authors reported good efficacy of UA on both illnesses; however, they reported unclear mechanism and suggested the need for further studies. Joseph et al. studied the expression rates of 542 genes associated with the mitochondrion structure and liver functioning in female rats. ${ }^{17,18} \mathrm{~A}$ significant effect on the expression of several genes was induced by UA only at the dose $600 \mu \mathrm{g} / \mathrm{mL}$ It was observed that a significant upregulation of genes associated with complexes (I) through (IV) in the electron transport chain resulted from UA. ${ }^{19}$

\section{PROVED BIOLOGICAL EFFECTS OF USNIC ACID}

\section{Usnic acid as an antioxidant and pro-oxidant}

Odabasoglu et al, reported that usnic acid possesses antioxidant effect when utilized against indomethacininduced ulcers in rat's stomach. The antioxidant effect of usnic acid is undoubtedly related to the ability to perform peroxyl radical scavenging, reduce hydroxyl radicals and to decrease the synthesis of nitrite. ${ }^{20}$ Rabelo et al, added that this effect is related to the capacity of usnic acid to increase intracellular ROS synthesis in these cells. ${ }^{21}$ In another study performed by Kohlhardt-Floehr et al, low concentrations of UA extracted from Xanthoparmelia farinosa (Vainio) and under physiological UVB intensity, exhibit an antioxidant function. ${ }^{22}$

\section{Usnic acid as cytotoxic and anti-proliferative agent}

Several studies showed that (-)-usnic acid inhabited the murine P388 leukemia assay and revealed cytotoxic activity against cultured L1210 cells, where it was concluded that p-tri-ketone moiety was essential for the optimum activity. ${ }^{23}$ Another study showed that (+)-usnic acid $(50 \mu \mathrm{g} / \mathrm{mL})$ decreased the cell counts of leukemic (K 562) and endometrial carcinoma cell culture (HEC$50){ }^{24,25}$ In 2005 reported that "usnic acid has antiproliferative activity against the wild-type p53 (MCF7) as well as the non-functional p53 (MDA-MB-231) breast cancer cell lines, and the lung cancer cell line H1299, which is null for p53". ${ }^{26}$ Where UA worked as either a systemic therapy or as a topical agent for the treatment of tumors. In was concluded that the antineoplastic activity of UA is not related to alterations in the formation and/or stabilization of microtubules. ${ }^{27}$

The cytotoxic activity of purified lichen metabolites was evaluated by Brisdelli et al, in three human cancer cell lines included "MCF-7 (breast adenocarcinoma), HeLa (cervix adenocarcinoma) and HCT-116 (colon carcinoma)".28 It was found that the highest cytotoxic activity against all cancer cell lines analyzed was higher than $25 \mathrm{mM}$ when compared with the other lichen.

\section{Usnic acid as an antimicrobial and antiprotozoal agent}

Interest in the antibiotic has decreased in the last three decades of the appearance of penicillin and synthetic antibiotics, but has returned to the forefront of interest since 1980 because of the emergence of antibiotic-resistant bacterial strains. ${ }^{4}$ Both optical enantiomers of UA are active against Gram-positive bacteria and mycobacteria, where several research studies and clinical trials have established the antibacterial properties of usnic acid. ${ }^{3}$

First studies focused on the sepsis inhabit by UA, where they found that gram positive bacteria are the more sensitive to UA than gram negative second group of the studies focused on the concentration where both enantiomers were tested the last groups focused on the action of (+) and (-) enantiomers on methicillin and mupirocin-resistant St. aureus strains. ${ }^{1,3}$ For example, in preliminary clinical trials, the researchers gave the volunteers a mouthwash with $1 \%$ UA was given, then they examine the oral bacterial flora on a regular time. They reported that the growth of Streptococcus mutants was selectively inhibited. ${ }^{29}$ Using standardized as ses ses, the in vitro weakness of pathogenic Gram positive and anaerobic bacteria toward usnic acid has been established. ${ }^{30}$ Also it was reported that usnic acid suppress the growth of Grampositive organisms responsible for body odor, and the ethoxydiglycol extracts of lichens containing $10 \%$ usnic acid on a wet weight basis has used as preserving in moisturizing cream. ${ }^{31}$ Several studies were reported the effectiveness of usnic acid against mycobacteriurn aureurn. ${ }^{32}$

The first study was in vitro assays, where UA and its salt suppress the growth of mycobacteriurn tuberculosis at relatively low concentrations. ${ }^{11}$ Similar result was found in Brazil study, where us nic acid exhibited activity against both resistant and susceptible strains, it is one of the little cases where an isolated substance from a natural source shows good antimicrobial activity. ${ }^{33}$ This effect isn't new, where it was used since long time ago in China. ${ }^{34}$ For mycobacterium tuberculosis, 30 patients received UA tablets $90 \mathrm{mg} /$ day (or $1.5 \mathrm{mg} / \mathrm{kg} / \mathrm{day}$ ) about $71 \mathrm{days}$, and for bronchitis, 91 patients were treated by $30 \mathrm{mg}$ UA t.d.s) where 10 days was considered the appropriate therapy period..$^{35}$

In another set of studies UA exhibited activity against methicillin-resistant Staphylococcus aureus particularly 
with cystic fibrosis patients and its potential use in the sterilization of surgical implants is being investigated. ${ }^{36}$ Gupta et al. indicated this efficacy to the disruption of the cell membrane. ${ }^{37}$ Also, reported that the primary effects of UA on B. subtilis and S. aureus are inhibition of RNA and DNA synthesis. Weakening of protein synthesis in $B$. subtilis and S. aureus seem to be indirect, as the effects were late, which suggest that they were reliant on RNA production inhibition. ${ }^{1}$

Recently, the valuable property of UA activity against protozoa was discovered, where the source of antiprotozoal medications is limited, and the licensed pharmaceuticals are highly toxic. ${ }^{3}$ In a previous study the researchers reported the inhibitor efficacy of usnic acid against the pathogenic protozoan Trichornonas vaginalis at reasonably low concentrations $(0.4 \mu \mathrm{g} / \mathrm{mL})$ than metronidazole $(0.6 \mu \mathrm{g} / \mathrm{mL}) .{ }^{18}$ The second study reported "leishmanicidal properties both in vitro and in vivo", intraregional administration of UA reduces in lesion weight and parasite body load. ${ }^{29}$ In another study the influence of various doses of (+) UA on the growth of trypanosomes (the epimastigote form), with UA at higher levels, 40 or $80 \mu \mathrm{g} / \mathrm{mL}$, caused lysis of parasite kinetoplasts and mitochondria without causing fundamental damage of host cells ${ }^{37}$ Other studies focused on the use of UA against plasmodium falciparum, the causative agent of malaria, where several studies determined the efficacy of the $\mathrm{IC}_{50}$ of UA, with different concentrations ranged from $15 \mu \mathrm{M}$, to $75 \mu \mathrm{M} .{ }^{38,39}$

\section{Usnic acid as antiviral agent}

The antiviral activity of UA was not detected till 1995, when Yamamoto et al. confirmed the influence of UA on the replication of carcinogenic Epstein-Barr virus, where inhibition by (+) UA was observed at $1.0 \mu \mathrm{g} / \mathrm{mL}$, while $(-)$ UA was less active at $5.0 \mu \mathrm{g} / \mathrm{mL} \cdot{ }^{40-43} \mathrm{In}$ another study, it was reported that (+)-usnic acid inhibited the cytopathic effects of herpes simplex type I and polio type 1 viruses in the infected kidney cells of the African green monkey. ${ }^{33}$

There is indirect evidence that the inhibition mechanism is related to the ability of UA to repress viral transcription, where the action of UA was specifically targeted at virus specific enzymes mediating the replication of viral nucleic acids. ${ }^{44-47}$ Another study showed good efficacy of UA on influenza $\mathrm{A}$, where anti-influenza activity of native (-)-UA is four times higher than the one of its $(+)$-counterpart, while activity of newly synthesized derivatives of (+)-UA appeared equal or higher than their (-)-UA counterpart, this confirmed that antiviral activity of usnic acid derivatives can be improved by side moieties introduction, where the modification with chalcones appeared to be the most effective. ${ }^{18}$

\section{Usnic acid algicidal agent}

The toxic action of UA on no symbiotic algae was studied. It was found that UA at the concentration of $10 \mu \mathrm{g} / \mathrm{mL}$ suppressed the growth of the single cell green alga Chlamydomonas Reinhard by 10-20\%. Usnic acid treatment did not affect gametogenes is as it was reported that UA at the concentration $50 \mu \mathrm{g} / \mathrm{mL}$ did not inhibit the growth of another green alga, Chlorella fusca. ${ }^{48}$

\section{Usnic acid as antiinflmmatory agent}

Inflammation was defined by Riella et al, as "a protective host response to foreign antigenic challenge or tis sue injury that, if unopposed, could lead to loss of tissue structure as well as function". ${ }^{49}$ In two models of inflammation "an acute rat paw edema and a chronic rat cotton pellet with $100 \mathrm{mg} / \mathrm{kg}$ oral dose", the antiinflammatory action of (+)-UA was similar to ibuprofen with a similar dose ${ }^{50}$ Another study reported that usnic acid protects lipopolys accharide produced mice acute lung injury by alleviating the inflammatory reactions and oxidative stress. Assessment of the anti-inflammatory action showed that usnic acid mitigated the expression of: "tumor necros is factor alpha (TNF-a), interleukin-6 (IL-6), interleukin-8 (IL-8) and macrophage inflammatory protein-2 (MIP-2)".

The analgesic and antipyretic actions of UA were estimated in two different studies conducted on mice. ${ }^{51}$ At $100 \mathrm{mg} / \mathrm{kg}$ oral dose level, UA showed a substantial analgesic effect as strong as that of acetic acid, while on oral dose levels up to $300 \mathrm{mg} / \mathrm{kg}$, UA also expressed notable antipyretic action determined after lipopolysaccharide-induced hyperthermia..$^{51}$

\section{Usnic acid as $U$ V filter}

In the last few years, the natural products from plants and lichens origin showed potential sunscreen effect as they can absorb the UV light and have antioxidant power. Where usinc acid ability to filter UV light and protect against it was assessed in both in vivo and in vitro studies it was found that UA is one of the best UVB filter when compared to references sunscreen named "Nivea sun Spray LSF 5".52

\section{Adverse effect of usnic acid and usage}

\section{Unsic acid induced hepatotoxicity}

Liver is the most organ exposed to toxic injuries, as all substances swallowed then absorbed and go directly to the liver. Adding to that the liver is the organ responsible for the metabolism and excretion of large number of substances. ${ }^{2}$ Usnic acid showed a good property to use as a treatment for different diseases, however it has been accompanied by marked liver injury (hepatotoxicity) when taken as a supplementary medication to induce weight $\operatorname{loss} .^{2}$

Pramyothin et al, studied hepatotoxic effects of UA in is olated rat hepatocytes receiving UA at a dose of 100 or $1000 \mu \mathrm{M}$ and noticed that "UA encouraged the release of 
hepatic transaminases (AST and ALT), reduced the content of glutathione, and caused loss of cell membrane integrity". ${ }^{5}$ Treatment with usnic acid and carbon tetrachloride $(\mathrm{CCl} 4)$ the hepatotoxin agent showed similar cellular responses, indicating that usnic acid may have the same hepatotoxic mechanisms as excited by CCl4. ${ }^{15}$ In another study, administration of $5 \mu \mathrm{M}$ UA for 16 hours in a mouse primary hepatocyte induced death in $98 \%$ of the cells which seemed to be related to cell necrosis.

They concluded that UA generated free radical that induced oxidative stress that is considered crucial to hepatotoxicity induced by UA. ${ }^{16}$ The toxic effects of usnic acid on human hepatoblastoma - HepG2 cells were described by Sahu et al. suggesting an oxidative mechanis $m$ of action of UA. ${ }^{13}$
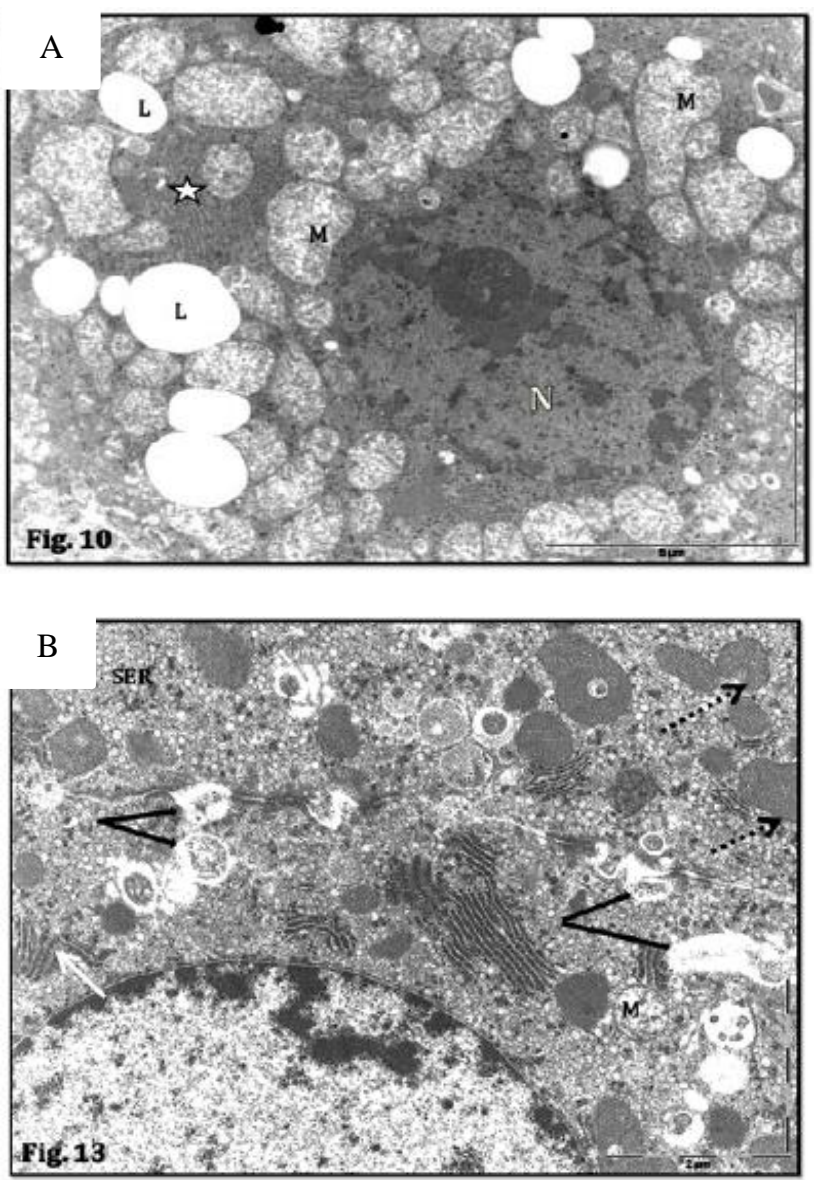

Figure 3: Picture taken by transmission electron microscope of hepatocyte from UA low dose group $(100 \mathrm{mg} / \mathrm{kg}$ ) (A) Slight affection of the cell organelles. Hepatocyte from high dose group $(300 \mathrm{mg} / \mathrm{kg})(B)$ Marked degeneration of the cell organelles. ${ }^{55}$

\section{Usnic acid induced genatotoxicity}

Although the in vitro studies performed on some human tumor cell cultures showed that UA did not damage DNA. ${ }^{26}$ A more recent in vitro study using DNA comet assay showed that usnic acid induced DNA damage at the dose of 60 and $120 \mu \mathrm{g} / \mathrm{mL}$, although no effect was noticed in the micronucleus test with V79 cells. ${ }^{53}$

On the other hand, the in vivo study conducted on mice consuming usnic acid at doses $25,50,100$, or $200 \mu \mathrm{g} / \mathrm{kg}$ using the micronucleus and DNA comet showed that UA had no genotoxicity. ${ }^{54}$ Both proteins, genetic materials in mouse spermatozoa showed no changes even after consumption of (+)-UA at the daily dose $200 \mathrm{mg} / \mathrm{kg}$ for 35 days. ${ }^{54}$

Upon assessing the chronic effect of UA on the hepatocytes of at low $(100 \mathrm{mg} / \mathrm{kg})$ and high dose $(300 \mathrm{mg} / \mathrm{kg})$ on the adult male rats, it was found that hepatocytes showed an increased lipid droplet, swollen mitochondria and fragmented rough endoplasmic reticulum indicating marked harmful effect of the cellular level induced by UA at high dose (Figure 3). ${ }^{55}$

\section{Usnic acid induced allergenicity}

According to Thune and Solberg, usnic acid is chemically linked to furocoumarin and shows allergic cross-reactivity, however, usnic acid does not classically cause photosensitivity. ${ }^{2}$ Another study showed that only the Dis omer is allergenic. ${ }^{56,57}$ Another study revealed that both the D- and L-isomers of UA were allergenic and that persons may react to one or both enantiomers. ${ }^{2}$ In 2006 study, it was reported that "four patients had positive patch test reactions to lichen acid mix and D-UA". Three of the four patients with patch-tested for the botanical deodorant had positive reactions. ${ }^{2}$

\section{Usnic acid induced effects on cardiovascular effects}

Several studies detect the effect of UA on the CVS, in 2010 study on guinea pig left atrium which in isolated organ bath. The author confirmed that "increasing of UA doses (1-800mM) produces a negative inotropic effect for concentrations more than $100 \mathrm{mM}$ ". This effect was associated with a strong diastolic contraction for concentrations above $500 \mathrm{mM}$.

These effects were permanent. Also, the dose more than $100 \mathrm{mM}$ also induced changes in the speed of the cardiac muscle contraction, increasing the time for both systole and diastole. ${ }^{58}$ Another study on human showed no change in cell viability of endothelial cells (Eary926) incubated 24 $\mathrm{h}$ with different concentrations of UA. ${ }^{2}$

Usnic acid induced sideffects on the adipocytes of fatty tissue

When the chronic effect of UA on the structure of adipocytes of the perirenal fat was assessed at low $(100 \mathrm{mg} / \mathrm{kg})$ and high dose $(300 \mathrm{mg} / \mathrm{kg})$ in the adult male rats, it was found that adipocytes became small with the appearance of capillary congestion and intercellular hemorrhages indicating negative impact of these tis sues induced by UA at high dose (Figure 4$).{ }^{17}$ 

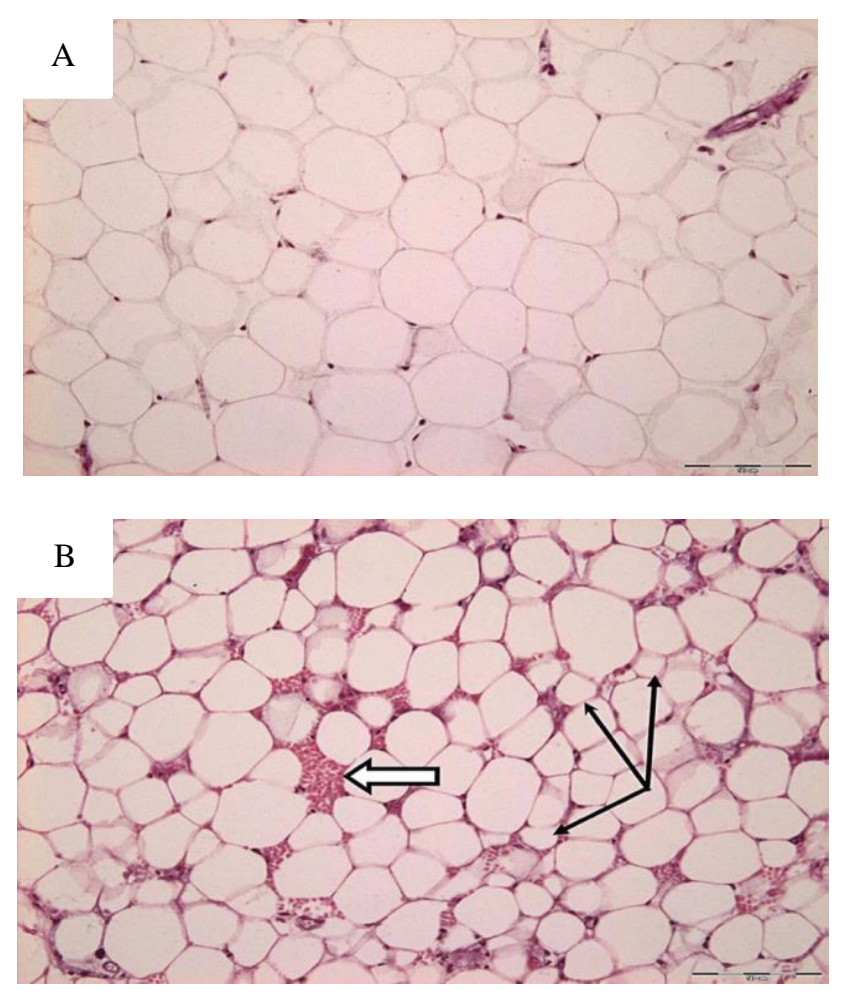

Figure 4: Picture taken by light microscope of adipocytes from UA low dose group $(100 \mathrm{mg} / \mathrm{kg})(\mathrm{A})$ Small-sized cells compared to the control. There is no signs of necrosis, fibrosis, or vascular changes.

Adipocytes from high dose group (300mg/kg) (B)

Marked decrease in cell size, marked capillary congestion and intercellular hemorrhage.

\section{CONCLUSION}

Even with the good scientific information, it is hard to confirm the use and safety of UA, due to the limitation of preclinical pharmacological studies. Moreover, the toxicological research to support the safety isn't enough. Hence, further studies are needed to determine the efficacy and safety of UA.

\section{Funding: No funding sources}

Conflict of interest: None declared

Ethical approval: Not Required

\section{REFERENCES}

1. Raizada N, Sachdeva KS, Sreenivas A, Vadera B, Gupta RS, Parmar M, et al. Feasibility of decentralised deployment of Xpert MTB/RIF test at lower level of health system in India. PLoS One. 2014;26;9(2):e 89301.

2. Maciąg-Dorszyńska M1, Węgrzyn G, GuzowKrzemińska B. Antibacterial activity of lichen secondary metabolite usnic acid is primarily caused by inhibition of RNA and DNA synthesis. 2014;353(1):57-62. Available at: https://www.ncbi.nlm.nih.gov/pubmed/24571086"F EMS Microbiol Lett.
3. Luzina OA, Salakhutdinov NF. Biological activity of usnic acid and its derivatives: Part 2. effects on higher organisms. Molecular and physicochemical aspects. Russian Journal of Bioorganic Chemistry. 2016;1;42(3):249-68.

4. Guo L, Shi Q, Fang JL, Mei N, Ali AA, Lewis SM, et al. Review of usnic acid and Usnea barbata toxicity. J of Env Sci and Heal, Part C. 2008;26(4):317-38.

5. Castle H, Kubsch F. The production of usnic, didymic, and rhodocladonic acids by the fungal component of the lichen Cladonia cristatella. Archives of biochemistry. 1949;23(1):158-60.

6. Taguchi H, Sankawa U, Shibata S. Biosynthesis of natural products. VII. Biosynthesis of usnic acid in lichens. Seasonal variation observed in usnic acid biosynthesis. Chemical and Pharmaceutical Bulletin. 1969; 17(10):2061-4.

7. Bjerke JW, Elvebakk A, Domínguez E, Dahlback A. Seasonal trends in usnic acid concentrations of Arctic, alpine and Patagonian populations of the lichen Flavocetraria nivalis. Phytochemistry. 2005;66(3):337-44.

8. Curd FN, Robertson AJ. Usnic Acid. Part I. Derivatives of methylphloroglucinol. Chem. Soc. 1933;0:437-44.

9. Komiya T, Shibata S. Formation of Lichen Substances by Mycobionts of Lichens. Isolation of (+) Usnic Acid and Salazinic Acid from Mycobionts of Ramalina spp. Chemical and Pharmaceutical Bulletin. 1969;17(6):1305-6.

10. Krishna DR, Ramana DV, Mamidi NV. In vitro protein binding and tissue distribution of $\mathrm{D}(+)$ usnic acid. Drug MetabolDrug Interact. 1995;12:53-63.

11. Krishna DR, Venkataramana D. Pharmacokinetics of $\mathrm{D}(+)$-usnic acid in rabbits after intravenous and oral adminis tration. Drug Metab Dispos. 1992;20:909-11.

12. Foti RS, Dickmann LJ, Davis JA, Greene RJ, Hill JJ, Howard ML, et al. Metabolism and related human risk factors for hepatic damage by usnic acid containing nutritional supplements. Xenobiotica. 2008;38:264-80.

13. Sahu SC, Amankwa-Sakyi M, O'Donnell MW, Sprando RL. Effects of usnic acid exposure on human hepatoblastoma HepG2 cells in culture. J Appl Toxicol. 2012;32(9):722-30.

14. Johnson RB, Feldott G, Lardy HA. The mode of action of the antibiotic, usnic acid. Arch. Biochem. 1950;28(3):317-23.

15. Pramyothin P, Janthasoot W, Pongnimitprasert N, Phrukudom S, Ruangrungsi N. Hepatotoxic effect of (+) usnic acid from Usnea siamensis Wainio in rats, isolated rat hepatocytes and isolated rat liver mitochondria. J Ethnopharmacol. 2004;90:381-87.

16. Han D, Matsumaru K, Rettori D, Kaplowitz N. Usnic acid-induced necrosis of cultured mouse hepatocytes: inhibition of mitochondrial function and oxidative stress. Biochem Pharmacol. 2004;67:439-51.

17. Al-Ahmadi AA, Al-Robai AA, Abo-Khatwa AN, Ali SS. Assessment of Usnic Acid (Lichen Usnea 
Articulata Extract) Safety on Lipid Profile, Adipocytes Morphology and Liver Functions in Adult Male Rats. JKAU: Med. Sci. 2013;20(2):4565.

18. Shtro AA, Zarubaev VV, Luzina OA, Sokolov DN, Kiselev OI, Salakhutdinov NF. Novel derivatives of usnic acid effectively inhibiting reproduction of influenza A virus. Bioorganic \& medicinal chemistry. 2014;22(24):6826-36.

19. Joseph A, Lee T, Moland CL, Branham WS, Fuscoe JC, Leakey JE, et al. Effect of (+)-usnic acid on mitochondrial functions as measured by mitochondria-specific oligonucleotide microarray in liver of $\mathrm{B} 6 \mathrm{C} 3 \mathrm{~F} \quad 1$ mice. Mitochondrion. 2009;9(2):149-58.

20. Odabasoglu F, Cakir A, Suleyman H, Aslan A, Bayir Y, Halici M, et al. Gastroprotective and antioxidant effects of usnic acid on indomethacin-induced gastric ulcer in rats. J Ethnopharmacol. 2006; 103(1):59-65.

21. Rabelo TK, Zeida'n-Chulia' F, Vasques LM, dos Santos JPA, da Rocha RF, Pasquali MAdB, et al. Redox characterization of usnic acid and its cytotoxic effect on human neuron-like cells (SH-SY5Y). Toxicol In Vitro. 2012;26:304-14.

22. Kohlhardt-Floehr C, Boehm F, Troppens S, Lademann J, Truscott TG. Prooxidant and antioxidant behaviour of usnic acid from lichens under UVB-light irradiation-studies on human cells . Journal of Photochemistry and Photobiology B: Biology. 2010;101(1):97-102.

23. Takai M, Uehara Y, Beisler JA. Usnic acid derivatives as potential antineoplastic agents. J Med Chem. 1979;22:1380-84.

24. Cardarelli M, Serino G, Campanella L, Ercole P, De Cicco NF, Alesiani O, et al. Antimitotic effects of usnic acid on different biological systems. Cell Mol Life Sci. 1997;53:667-72.

25. Kristmundsdottir T, Aradottir HA, Ingolfsdottir K, Ogmundsdottir HM. Solubilization of the lichen metabolite (+)-usnic acid for testing in tis sue culture. J Pharm Pharmacol. 2002;54:1447-52.

26. Mayer M, O’Neill MA, Murray KE, SantosMagalha es NS, Carneiro-Lea o AM, Thompson AM, et al. Usnic acid: a non-genotoxic compound with anti-cancer properties. Anti-cancer Drugs. 2005;16(8)805-9.

27. O’Neill MA, Mayer M, Murray KE, Rolim-Santos HM, Santos-Magalha es NS, Thompson AM, et al. Does usnic acid affect microtubules in human cancer cells? Brazil J Biol. 2010;70:659-64.

28. Brisdelli F, Perilli M, Sellitri D, Piovano M, Garbarino JA, Nicoletti M, et al. Cytotoxic activity and antioxidant capacity of purified lichen metabolites: an in vitro study. Phytotherapy research. 2013;27(3):431-7.

29. Ingolfsdottir K. Usnic acid. Phytochemistry. 2002;61:729-36.

30. Ramos DF, Almeida da Silva PE. Antimycobacterial activity of usnic acid against resistant and susceptible strains of Mycobacterium tuberculosis and non- tuberculous mycobacteria. Pharm Biol. 2010;48(3):260-3.

31. Frankos VH. NTP nomination for usnic acid and Usnea barbata. 2004. Available at: http://ntpserver.niehs.nih.gov/Kk

32. Francolini I, Norris P, Piozzi A, Donelli G, Stoodley P. Usnic acid, a natural antimicrobial agent able to inhibit bacterial biofilm formation on polymer surfaces. Antimicrob Agents Chemother. 2004;48:4360-65.

33. Gupta VK, Verma S, Gupta S, Singh A, Pal A, Srivastava SK, et al. Membrane-damaging potential of natural L-(-)-usnic acid in Staphylococcus aureus. Eur J Clin Microbiol Infect Dis. 2012 Dec;31(12):3375-83.

34. De Carvalho EA, Andrade PP, Silva NH, Pereira, EC, Fiqueiredo RC. Effect of usnic acid from the lichen Cladonia substellata on Trypanosoma cruzi in vitro: an ultrastructural study, Micron. 2005;36(2):155-61.

35. Luzina OA, Salakhutdinov NF. Biological activity of usnic acid and its derivatives: Part 1 . Activity against unicellular organisms. Russian J Bioorg Chemis. 2016;42(2):115-32.

36. Emmerich R, Giez I, Lange OL, Proksch P. Toxicity and antifeedant activity of lichen compounds against the polyphagous herbivorous insect Spodoptera littoralis. Phytochemistry. 1993;33(6):1389-94.

37. Polovinka MP, Salakhutdinov NF, Luzina OA, Glupov VV, Serebrov VV, Dubovskii IM, et al. Patent no. 2328493, Byull. Izobret. 2008:19.

38. Nikolić V, Stanković M, Nikolić L, Nikolić G, IlićStojanović S, Popsavin M, et al. Inclusion complexes with cyclodextrin and usnic acid. Journal of Inclusion Phenomena and Macrocyclic Chemistry. 2013;76(1 2):173-82.

39. Bomfim RR, Araújo AA, Cuadros-Orellana S, Melo MG, Quintans-Junior LJ, Cavalcanti SC, et al. Larvicidal activity of Cladonia substellata extract and usnic acid against Aedes aegypti and Artemia salina. Latin Ame J of Pha. 2009;28(4):580-4.

40. Broksa B, Sturdikova M, Pronayova N, Liptaj T. (-)Usnic acid and its derivatives. Their inhibition of fungal growth and enzyme activity. Die Pharmazie. 1996;51(3):195-6.

41. Cocchietto M, Skert N, Nimis P, Sava G. A review on usnic acid, an interes ting natural compound. Natur wis senschaften. 2002;89(4):137-46.

42. Campanella L, Delfini M, Ercole P, Iacoangeli A, Risuleo G. Molecular characterization and action of usnic acid: a drug that inhibits proliferation of mouse polyomavirus in vitro and whose main target is RNA transcription. Biochimie. 2002;84(4):329-34.

43. Schimmer O, Lehner $H$. Untersuchungen zur Wirkung von Usninsäure auf die Grünalge Chlamydomonas reinhardii. Archives of Microbiology. 1973;93(2):145-54.

44. Vijayakumar CS, Viswanathan S, Reddy MK, Parvathavarthini S, Kundu AB, Sukumar E. Antiinflammatory activity of (+)-usnic acid. Fitoterapia. 2000;71:564-566.55 
45. Sahu SC, O'Donnell MW, Sprando RL. Interactive toxicity of usnic acid and lipopolysaccharides in human liver HepG2 cells. J Appl Toxicol. 2012;32(9):739-49.

46. Huang Z, Zheng G, Tao J, Ruan J. Anti-inflammat ory effects and mechanisms of usnic acid. Journal of Wuhan University of Technology-Materials Science Edition. 2011;26(5):955-9.

47. Okuyama E, Umeyama K, Yamazaki M, Kinoshita Y, Yamamoto Y. Usnic acid and diffractaic acid as analgesic and antipyretic components of Usnea diffracta. Planta Med. 1995;61:113-5.

48. Riella KR, Marinho RR, Santos JS, Pereira-Filho RN, Cardoso JC, Albuquerque-Junior RL, Thomazzi SM. Anti-inflammatory and cicatrizing activities of thymol, a monoterpene of the essential oil from Lippia gracilis, in rodents. J of Eth. 2012;143(2):65663.

49. Rancan F, Rosan S, Boehm K, Fernández E, Hidalgo ME, Quihot W, et al. Protection against UVB irradiation by natural filters extracted from lichens. Journal of Photochemistry and Photobiology B: Biology. 2002;68(2):133-9.

50. Favreau JT, Ryu ML, Braunstein G, Orshansky G, Park SS, Coody GL, et al. Severe hepatotoxicity as sociated with the dietary supplement LipoKinetix. Annals of internal medicine. 2002;136(8):590-5.

51. Neff GW, Reddy KR, Durazo FA, Meyer D, Marrero R, Kaplowitz N. Severe hepatotoxicity associated with the use of weight loss diet supplements containing ma huang or usnic acid. J Hepatol. 2004;41(6):1062-4.

52. Sanchez W, Maple JT, Burgart LJ, Kamath PS. Severe hepatotoxicity as sociated with use of a dietary supplement containing usnic acid. In Mayo Clinic Proceedings. 2006;81(4):541-4.
53. Yellapu RK, Mittal V, Grewal P, Fiel M, Schiano T. Acute liver failure caused by 'fat burners' and dietary supplements: a case report and literature review. Can J Gastroenterol. 2011;25:157-60.

54. Leandro LF, Munari CC, Sato VL, Alves JM, de Oliveira PF, Mastrocola DF, et al. Assessment of the genotoxicity and antigenotoxicity of (+)-usnic acid in V79 cells and Swiss mice by the micronucleus and comet assays. Mutation Research/Genetic Toxicology and Environmental Mutagenesis. 2013;753(2):101-6.

55. Al-Ahmadi AA, Ayuob NN, Ali SS, Al-Robai AA, Abo-Khatwa NA. Effect of (+)-Usnic Acid as a Fat Burner on the Rat Hepatocyte; Correlated Histological and Biochemical in vivo Study. J Anim Vet Adv. 2012;11(9):1368-77.

56. Ivanova V, Bačkor M, Dahse HM, Graefe U. Molecular structural studies of lichen substances with antimicrobial, antiproliferative, and cytotoxic effects from Parmelia subrudecta. Preparative biochemistry \& biotechnology. 2010 Sep;40(4):377 88.

57. Thune PO, Solberg YJ. Photosensitivity and allergy to aromatic lichen acids, Compositae oleoresins and other plant substances. Contact Dermatitis. 1980;6(2):81-7.

58. Mitchell JC, Shibata S. Immunologic Activity of Some Substances Derived from Lichenized Fungi** From the Division of Dermatology, Department of Medicine, The University of British Columbia. J Invest Dermatol. 1969;52(6):517-20k.

Cite this article as: Alahmadi AA. Usnic acid biological activity: history, evaluation and usage. Int J Basic Clin Pharmacol 2017;6:2752-9. 